\title{
Accessibility and Inclusive Tourism Development: Current State and Future Agenda
}

\author{
Brielle Gillovic * and Alison McIntosh (1) \\ School of Hospitality and Tourism, Auckland University of Technology, Auckland 1010, New Zealand; \\ alison.mcintosh@aut.ac.nz \\ * Correspondence: brielle.gillovic@aut.ac.nz
}

Received: 8 October 2020; Accepted: 19 November 2020; Published: 21 November 2020

\begin{abstract}
Accessibility constitutes one important consideration in the field of scholarship relating to inclusive tourism development because it is fundamentally about the inclusion of people with disabilities in tourism and in society. This conceptual paper maps how accessible tourism is currently positioned against an established framework of inclusive tourism development and gives examples of relevant accessible tourism studies to recommend a future agenda for more inclusive outcomes that move towards sustainability. The seven elements of Scheyvens and Biddulph's (2018) conceptual framework for inclusive tourism development form an appropriate and useful tool upon which to examine the current state of accessible tourism. The application of this framework reveals that we still have some way to go. We conclude this paper with a future agenda that posits attention to all seven elements of the inclusive tourism framework for accessible tourism, notably, to increase the involvement of people with disabilities as tourism producers and consumers; increase their self-representation and participation in decision-making; transform power relations; reimagine tourism places and people; and break down social barriers. We especially urge researchers to examine the dominant ableist discourse, to consider how our inquiry can be more participatory and inclusive, and to seek to bridge inquiry, industry and community.
\end{abstract}

Keywords: accessible tourism; disability; inclusive tourism; sustainability

\section{Introduction}

Tourism scholars continue to question how the tourism industry and tourism research might drive a more inclusive and sustainable future. This is certainly the case with respect to reducing the current marginalisation or exclusion of people with disabilities in tourism by bringing them into the industry in ways that directly benefit them, or that they can gain more control over [1]. As tourism has long been positioned by scholars as exclusionary, there is a continued need to address the industry's lack of accessibility that creates social inequality [2]. With this purpose in mind, the aim of this conceptual paper is to map how accessible tourism is currently positioned against the framework of inclusive tourism development and to give examples of relevant accessible tourism studies to recommend a future agenda for more inclusive outcomes that move towards sustainability.

Considered as both an analytical concept as well as an aspirational ideal, inclusive tourism development "can be used to evaluate current tourism practices to help detect where changes are needed, as well as to guide new tourism development" [2] (p. 587). Accessibility constitutes one important consideration in the field of scholarship relating to inclusive tourism development in the drive for innovation and new recommendations to counter socio-economic barriers and exclusions. Whilst the seven elements of inclusive tourism development thus form an appropriate and useful framework upon which to map the current state of play of accessible tourism scholarship so as to 
propose a future agenda, as is proffered in this paper, it does not provide a means for recommending specific initiatives to combat the social barriers imposed by the tourism industry.

\section{Situating Accessibility within Inclusive Tourism Development for Sustainable Outcomes}

Before mapping the current position of accessible tourism scholarship against the seven elements of inclusive tourism development, the paper considers the background context of the field of study and discusses the concepts of disability, sustainability, accessibility and inclusive tourism development.

\subsection{Disability}

Disability is ubiquitous worldwide [3]. It is generally accepted that 15 percent of the global population, or 1 billion people, live with disability. The number of people who are directly or indirectly affected by disability rises to 30 percent of the global population, or 2 billion people, when the family members and carers of people with intellectual disabilities are considered [4]. In Western developed nations, it is generally accepted that 15 to 20 percent of the population live with disability, and disability is even more prevalent among less developed, vulnerable populations $[5,6]$. It is estimated that by the year 2050, the number of people living with disability globally will have risen to 1.2 billion [4]. This rise will be attributable to population ageing [7], the rise of chronic health problems and non-communicable diseases [8], increasing life expectancies, decreasing rates of child mortality [9], and better tools for identifying and measuring disability [4].

While the statistics provide a measure of disability, disability discourse can better guide our understanding. The medical and social models of disability have informed much of the previous disability discourse [6]. The medical model of disability provided a perspective of disability that emphasised the impairment before the individual, and perpetuated notions of abnormality or loss in functional ability. As such, it prioritised the need for a treatment or cure, intervention or accommodation. In contrast, the social model of disability has challenged the previous medical discourse. Instead, it argues that it is society that disables the individual rather than their impairment, and thereby requires a social solution to reduce barriers and enable participation. A contemporary perspective of disability acknowledges, understands and celebrates the diversity and multiplicity of disability [8]. Disability is likely to be a feature of most people's lifespans, whether in a temporary or permanent capacity; and whether it affects people directly, or indirectly through someone close to them [10-12]. The inevitability of these socio-demographic shifts will present a range of future implications for our global society, and by extension, tourism $[10,13]$. Scholars have recognised this correlation between ageing, disability and tourism, and what this means, and will mean, for tourists and residents alike [5,14]. Notably, "studies on disability and tourism broaden the diversity of a field by including 10-20 percent of the population who had previously been excluded from our understanding" [1] (p. 142).

\subsection{Sustainability}

The tourism industry and tourism scholarship have long advocated for the sustainable development of tourism. Sustainable development seeks to balance the protection of the environment, the promotion of economic growth, and the maintenance of social and cultural integrity, both in the present and in the future [15]. Much of this attention has been directed toward the economic and environmental sustainability of the industry. Less of this attention has been directed toward issues of social sustainability, and especially neglected are considerations of the implications of ageing and disability which undoubtedly present challenges for the future of tourism $[5,16]$. Notwithstanding the importance of economic growth and environmental responsibility, a broader sense of human dignity, respect and welfare $[2,17]$ means there is a need to more fully consider the wider social benefits of tourism.

The United Nations (2006) Convention on the Rights of Persons with Disabilities recognises the citizenship rights of people with disabilities, and is underpinned by principles of respect and equality, access and inclusion [18]. Of particular relevance to this paper is the citizenship right to 
travel $[10,19,20]$. Specifically, Article 9 refers to access to transportation and the built environment, and Article 30 refers to participation in all areas of 'cultural life,' including sport, leisure and tourism [21]. Ratified in 2015, the United Nations 2030 Agenda for Sustainable Development and the 17 Sustainable Development Goals provide a framework for balancing the economic, environmental and social dimensions of sustainable development [22]. The purpose of that framework is to foster equitable and inclusive societies, where respect for human rights and human dignity, as well as equal opportunities, are realised [22]. To this end, the Agenda and Goals are guided by the purpose and principles of the Charter of the United Nations and reaffirm the importance of the Universal Declaration of Human Rights, as well as the Convention on the Rights of Persons with Disabilities [23]. Embedded within these Goals are considerations pertaining to disability.

Despite attention to the Sustainable Development Goals, some individuals and groups, because of their gender, age, ethnicity, poverty, sexuality or disability [24], lack power and/or voice, and are excluded from development [2]. Central to the Sustainable Development Goals is the principle of inclusion, and development, therefore, will be inclusive only when said individuals and groups are empowered and have their voices heard. We cannot ignore disability and, especially, the perspectives and experiences of people with disabilities, when addressing the Sustainable Development Goals in tourism $[1,5]$.

\subsection{Accessibility}

Like sustainability [25], accessibility is a contemporary tourism issue [13]. In its broadest sense, accessibility ensures the development of products, services and environments that allow everyone to use and derive benefit from them. An example is that of universal design principles, which enable usability by people with disabilities without the need for adaptation. It is important to consider where disability and tourism fit within the broader sustainability agenda, as well as the need for accessibility and inclusion in tourism [26]. People with disabilities are a historically excluded and socially marginalised group that lack power and voice [27]. They have faced, and continue to face, barriers to their full and effective participation and inclusion in the community and in cultural life, whether that be the arts, sport and recreation $[1,23,28]$. While tourism is considered an integral part of modern life, for people with disabilities, it is not always accessible or inclusive [29,30]. People with disabilities are not always able to partake in this leisure activity due to its barrier-laden and socially exclusive nature [6,31]. That said, tourism has the potential to enhance the quality of life and life satisfaction for people with disabilities, through the likes of personal development and social interaction [32,33]. Such benefits and outcomes should be a priority with regard to a population who are denied all sorts of different opportunities in their day-to-day lives [34,35].

Participation in tourism is fundamental to enjoying all that citizenship represents. As such, tourism scholars have increasingly been concerned with the participation and inclusion of people with disabilities [31]. Scholars have come some way in addressing disability in tourism [13]. The concept of accessible tourism "enables people with access requirements, including mobility, vision, hearing and cognitive dimensions of access, to function independently and with equity and dignity through the delivery of universally designed tourism products, services and environments" [10] (p. 34). While the accessible tourism agenda, undoubtedly, has evolved in its sophistication [1], it has been somewhat devoid of an inclusive agenda.

\subsection{Inclusive Tourism}

Inclusive tourism is an analytical concept and an aspirational ideal [2]. Typically perceived from a domineering neoliberal perspective, tourism development has been pursued by governments and operators alike for its economic outcomes [36-38] and, today, comprises one of the world's largest and growing industries $[39,40]$. However, "as tourism expands at a seemingly insatiable pace, the inequalities become increasingly evident and so too does the need for more complex and nuanced understandings of them" [41] (p. xv). To this end, it has been argued that tourism's 
"full potential is squandered and its promise of many powerful benefits for humanity remains unfulfilled" [17] (p. 1193). Indeed, tourism has long been critiqued for its exclusive nature. Tourism scholarship, too, has been remiss in its lack of inclusion of certain individuals and groups at the margins of society $[42,43]$. Those who are "othered, omitted, overlooked or ostracised" in and from tourism are individuals and groups marginalised as a result of various identity markers and their intersectional nature [1] (p. 140). Therefore, in viewing tourism through a lens of social justice, we can read tourism "as an assertion of power and privilege" and must give greater thought to how we might ratify the right to tourism [44] (p. 1927).

Critical tourism scholars have increasingly explored the perspectives of such overlooked populations whose voices are underrepresented and marginalised $[45,46]$, the common denominator being the subjugation and exclusion of the 'other' [47,48]. Understood as a hopeful, critical and moral turn, this inquiry is oriented toward advocacy and a more inclusive view of tourism that promotes human rights and social justice within the industry and inquiry related to it $[46,49,50]$. By acknowledging past non-participation and exclusion in tourism, we can consider ways to enable future participation and inclusion in authentic and meaningful ways. In this way, inclusive tourism "can add value to tourism knowledge and understandings by seeking to explicitly overcome the exclusionary tendencies of tourism and to ensure that a wider range of people participate in and benefit from tourism endeavours" [2] (p. 590). As such, it is thought to be a transformative form of tourism; transformative in "addressing inequality, overcoming the separation of different groups living in different places, challenging stereotypes or generalised histories, and opening people up to understanding the situation of minorities" [2] (p. 592).

In defining the concept of inclusive tourism, Scheyvens and Biddulph put forward seven different elements of inclusive tourism development which they argue constitute lines of inquiry in investigations of tourism's inclusiveness [2]. Discussion of these elements can also inform a consideration of the potentials and limitations for tourism to generate wider socio-economic impacts for more equitable and sustainable outcomes. The first element, marginalised people as tourism producers, is about "overcoming barriers to disadvantaged groups' access to tourism as producers." The second element, marginalised people as tourism consumers, is about "overcoming barriers to disadvantaged groups' access to tourism consumers." The third element, self-representation in dignified and appropriate ways, is about telling the stories, and representing the culture, of marginalised people in meaningful ways. The fourth element, power relations challenged in and beyond tourism, is about "challenging dominant power relations." The fifth element, the widening of participation in tourism decision-making, is about "who can contribute to the decision-making about development of tourism." The sixth element, changing the tourism map to involve new people and places, is about "providing opportunities for new places to be on the tourism map." The seventh element, promotion of mutual understanding and respect, is about "encouraging learning, exchange and mutually beneficial relationships which promote understanding and respect between 'hosts' and 'guests'" [2] (p. 593).

Ultimately, Scheyvens and Biddulph attest that these seven elements may be applied to evaluate the degree to which tourism development is inclusive [2]. Our intention here is not to critique the established framework but rather to apply it to guide our own evaluation of tourism in terms of its accessibility for people with disabilities so as to shed light on a future agenda for accessible tourism in the broader context of sustainability. Scheyvens and Biddulph [2] posit that accessible tourism is just one aspect of inclusive tourism as the latter more broadly considers all forms of social and economic exclusion and division, not just accessibility. It could be argued, however, that such broad scoping does not sufficiently grant attention to specific excluded or marginalised groups. While Darcy et al. have commended Biddulph and Scheyvens' [26] definition of inclusive tourism for encompassing "all forms of marginality and intersectionality," they argue that it is too broadly focused and not specific enough to people with disabilities [1] (p. 141).

This paper thereby puts forth the view that the conceptual framework for inclusive tourism development, as an analytical tool, is complementary to considering the scope of work on accessible 
tourism and we advocate its use for examining the current state of accessible tourism. In this way, the degree to which accessible tourism development is inclusive may be determined by an assessment of the seven elements of the framework. As such, we now apply the framework of inclusive tourism development to conceptually map the current position of accessible tourism and give examples of relevant accessible tourism studies to recommend a future agenda. That is, we seek to examine "the tourism industry as it currently is, and also what it could be" [51] (p. 859).

\section{Conceptual Approach and Limitations}

In this paper we use a conceptual approach to explore the degree to which accessible tourism development is inclusive, as determined by an assessment of the seven elements of the conceptual framework by Scheyvens and Biddulph (2018). To achieve this, we drew upon relevant examples from the published literature on accessible tourism to illustrate how it could apply to each of the seven elements of the framework. We considered where the most notable gaps existed in relation to our interpretation of the elements of the framework. These gaps then informed our discussion of a future research agenda for accessible tourism. Noting that the examples we used could apply across more than one of the seven elements, we recognise the plurality and potential for differing interpretations on our findings. We also recognise that the inclusive tourism development framework, as an analytical tool, was designed by Scheyvens and Biddulph (2018) with a broader agenda for inclusive tourism beyond just accessibility. Whilst our discussion here is only a snapshot of how the framework can be applied to the accessible tourism agenda, we recommend that future researchers may wish to provide a more systematic review of the literature to critique the applicability of the framework for future considerations of accessible tourism and sustainability.

\section{Applying the Conceptual Framework for Inclusive Tourism Development: A Future Agenda for Accessible Tourism}

\subsection{People with Disabilities as Tourism Producers}

The first element of inclusive tourism development considers how different groups of people-in this case, people with disabilities — can be engaged in tourism as producers, that is, in "roles as owners, entrepreneurs, employees and regulators" [2] (p. 598). Generally speaking, people with disabilities have limited access to, and participation in, the labour market, and there is a lack of accessible workplaces with reasonable accommodations in place [23]. In tourism, too, there is minimal evidence, anecdotal or otherwise, to suggest that people with disabilities are engaged as producers to any great extent. The studies that do exist are overwhelmingly focused on people with disabilities as employees, principally within the hospitality sector and mostly in hotels. For instance, some studies have considered the barriers to, and challenges in, employing people with disabilities in hotels [52], or the benefits to, and outcomes for, hospitality organisations that employ people with disabilities [53-55]. Human resource policies and practices in hotels that employ people with disabilities have also been considered [56-58], as well as employer perspectives on employing people with disabilities in hospitality organisations [59-61]. Guest and consumer perspectives on people with disabilities as employees in hotels and restaurants are less studied $[62,63]$.

Fewer studies have examined hospitality organisations that operate as social enterprises and provide employment opportunities to people with disabilities [64]. The social innovation, 'Brownies \& Downies,' for instance, was born from a desire to see more people with disabilities playing a part in the hospitality sector, and by extension, wider society. The coffee shop concept, which began in the Netherlands and has now expanded throughout Europe and to South Africa, involves training centres, placement providers and coffee shops where people with intellectual disabilities are engaged in the preparation and serving of coffee and food [65].

While the studies mentioned above have focused on the employment of people with disabilities in the hospitality sector, there is no reason to suggest that similar studies could not be undertaken 
in the tourism sector. However, "one of the biggest challenges for inclusive tourism is to encourage responsible production of tourism by existing tourism businesses" [2] (p. 598). In any event, there is little evidence to suggest that people with disabilities are engaged in tourism as producers, whether that be as employees, or in the capacity of owners, entrepreneurs or regulators. The studies that do exist attest to the continued social barriers for people with disabilities as producers, compounded by the attitudes of employers in the industry as well as industry notions of service training, delivery and professionalism [66]. What becomes clear, then, is that greater future attention should be directed to engaging people with disabilities as tourism producers.

\subsection{People with Disabilities as Tourism Consumers}

The second element of inclusive tourism development considers how different groups of people-in this case, people with disabilities-can be engaged in tourism as consumers [2]. It is this focus on extending access to, and participation in, tourism, beyond the major markets, that serves as a key similarity between inclusive tourism and accessible tourism. Certainly, much of the accessible tourism literature has centred upon people with disabilities as tourism consumers, from both demand- and supply-side perspectives. It is oriented toward an economic or market perspective $[67,68]$, and how accessibility can be viewed as part of triple bottom line sustainability [5].

It is widely agreed that the industry, for the most part, has failed to interact with issues pertaining to the access to, and participation in, tourism by people with disabilities' [69-71]. People with disabilities are somewhat misunderstood, largely under-served, and even ignored, as a group of consumers, and as a viable segment of the market $[30,72,73]$. Operators do the bare minimum to meet legislative requirements [74], and governments are largely reactive rather than proactive [75]. Within the industry, a pervasive assumption is that people with disabilities constitute a minority market that requires considerable investment for low return and profitability [43,67]. Operators tend to want tangible proof of the benefits this market can bring before committing to providing or improving accessibility $[5,76]$. As such, the economic rationale supporting the provision or improvement of accessibility is the driver for operators and industry alike [72,77]. People with disabilities should be viewed as both "market segment" [1] (p. 142), and as "part of every market segment" [78] (p. 222).

Indeed, many studies have attested to the economic outcomes that can accrue to businesses and industry alike when accessibility is provided for $[5,76]$. Accessibility contributes to tourism activity and occupancy, increases the customer base and market share, reduces effects of seasonality, exploits competitive advantages, improves profitability, and enhances destination competitiveness [5,71,79]. Clearly, there is much evidence to suggest this is a significant and potentially lucrative market moving forward [73,80], despite the fact that there is a limited number of industry-based case studies to showcase such benefits [13]. Evidence shows that people with disabilities do engage in independent travel and there is a greater need to hear about their needs and experiences as consumers. With regard to accessibility, there is a future need to consider the personalisation of tourism supply [81], necessitating a greater understanding of the motives, decision-making behaviour, needs and experiences of people with disabilities as tourism consumers.

\subsection{Self-Representation in Dignified and Appropriate Ways}

The third element of inclusive tourism development considers the representation of marginalised people - in this case, people with disabilities—in a dignified and appropriate manner, and in meaningful ways [2].

A number of tourism scholars have suggested that disability is largely treated as a singlerather than multi-dimensional construct, and people with disabilities as a homogenous rather than heterogenous group $[6,82,83]$. If tourism is to be accessible and inclusive, then a recognition of the diversity of disability, and an individual's embodiment of that, is key [13]. Each individual's dimension of disability, level of support needs and requirement for assistive technologies, in addition to their interaction with the tourism environment, will ultimately shape the experience they derive $[5,18,80]$. 
There has thus been a shift toward better understanding the embodied ontologies of people with disabilities $[84,85]$. This is founded on the recognition that, for people with disabilities, tourism is a multi-sensory, bodily experience where, for the non-disabled, it is predominantly visual $[48,83,86]$.

To this end, a growing number of studies have explored the perspectives and experiences of people with different dimensions of disability. Mostly, such studies have focused on people with physical disabilities, or mobility impairments [69,87], or people with sensory disabilities, and particularly those with vision impairments $[70,80,85]$. The agenda is not necessarily inclusive of different impairment types [74]. Increasingly, however, other dimensions of disability are being explored, for instance, psychological or psychiatric impairments, such as people with dementia [88] or people with intellectual disabilities [89]. Interestingly, notions of ability versus disability are ableist and assume independence [82]. Yet travel is not always independent, and some people with disabilities are in a situation of dependency, wherein they will travel with a companion or carer [89,90]. In addition, recognition is being granted to the relational dimension of travel, where studies are including carers, family members and companions of people with disabilities [91,92]. All of these perspectives "ought to be heard if the aim of scholarly inquiry is to conceptualise the tourist experience more comprehensibly and responsibly" [93] (p. 93).

Well-reported in the literature are the positive outcomes people with disabilities derive from partaking in tourism [94,95]. Tourism affords a number of intra- and interpersonal benefits, whether that be for psychological or physical health, for self-confidence and self-development, or for social interaction and inclusion $[35,69,88]$. Most notably, a sense of quality of life and life satisfaction are asserted through tourism [76,92]. Tourism can represent a 'normal' or ordinary life for people with disabilities, presenting the potential to exert a sense of independence and autonomy [82,92]. Tourism, uniquely, provides a setting where people with disabilities may be relieved of the typical 'role' they experience in their everyday life, where they are, or at least are perceived as, objects of care, and by contrast are "overcoming self-doubt, redefining [themselves] and building self-confidence" [96] (p. 87). In fact, scholars have suggested that "tourism represents a metaphor for recovery" [35] (p. 958), and it can be a site of resistance and/or transformation [97]. Conversely, tourism can perpetuate anxiety and uncertainty in an overly stimulating and unfamiliar tourism environment $[70,85,86]$. Furthermore, people with disabilities experience disembodiment [91] and stigma [82,90,98]. Recognising the benefits of tourism for people with disabilities and their carers/travel companions, and the social barriers imposed by the tourism industry and wider social stigma, there is a future need to examine the social and relational nature of tourism, and shift focus from a medical to social view of disability [81].

\subsection{Power Relations Transformed in and beyond Tourism}

The fourth element of inclusive tourism development considers the transfer of power to previously marginalised people - in this case, people with disabilities—so as to transform power relations in and beyond tourism [2]. In fact, Scheyvens and Biddulph [2] propose that all of the elements, together, "provide potentially incremental contributions to the larger, long-term goal of transforming power relations and ending social exclusion" [2] (p. 602).

A key theme in the literature is the issue of tourism (non-)participation. There is a common misconception that people with disabilities cannot or do not travel $[69,96]$. As seen in the previous section, tourism is designed with the mobile and functional in mind [99] and, in this way, marginalises "those with different bodies and/or minds" [43] (p. 1262). Because of this, people with disabilities subsequently negotiate, or even surrender, their participation in tourism [35]. Accessible tourism is about advocating the right to travel and, therefore, necessitates the removal of barriers that otherwise prevent or constrain participation [96]. Taking a supply-side perspective, studies largely focus on the barriers, constraints and managerial implications of access-related issues $[18,87,96,100]$. Barriers, for instance, are typically environmental, intrinsic or interactive in nature [31], and examples include the likes of a lack of physical access, inaccurate or inadequate information, negative attitudes and discrimination $[71,90,91]$. Some barriers can be negotiated, but not all, as they rely on a complex 
interplay that is intrinsic to the individual and interactive with the socially constructed tourism environment $[80,84]$.

Mitigating barriers to participation and improving accessibility, "is in the broadest sense, an attack on the legal, political, social and economic structures that underpin and perpetuate their existence" [6] (p. 553). To this end, scholars have highlighted the importance of viewing disability as a social construct [13]. It is not the individual's impairment which is disabling, rather it is the complex interactions of the environment and society which denies their participation and inclusion [13,92].

Tourism does not occur in a 'social vacuum' [101]. The social restrictions that people with disabilities face every day [102] are still imposed upon them, and potentially internalised, when travelling [97,98]. People with disabilities are subjected to a sometimes judgmental, disapproving, and invalidating gaze of others-whether industry personnel, other tourists, or the host community-and to their negative attitudes and social stigma $[6,28,100])$. "Negative attitudes focus on negative behaviours, such as avoidance of people with disabilities, and apathetic behaviour in which people behave as if individuals with disabilities do not exist" [76] (p. 165). People with disabilities are "left out, left behind, excluded, waiting, passive, disenfranchised, less than, stigmatised, put down, unable, diminished, powerless, discriminated against" [71] (p. 195). Industry personnel, for instance, are often described as being apathetic and ignorant, insensitive and lacking empathy $[68,70]$. In this way, tourism environments can be sites of marginalisation and inequality. Yet, they can also serve as sites of resistance and/or transformation for people with disabilities, by way of normalising and/or challenging the presence of disability $[46,97]$. It is ultimately the attitudes of others that determine whether the tourism experience is positive or negative for people with disabilities [80,85].

Daruwalla and Darcy [6] have cautioned that such disengagement and discrimination is psychological, and there thus remains a future need to measure and analyse existing attitudinal barriers as well as the potential for wider attitudinal change [6]. Viewing disability as a social construct "provides the context for understanding the relationship between the individual's lived experience, society's attitudes and the focus on creating environments that enable independent, equitable and dignified participation" [82] (p. 2). Aitchison [99] has suggested that the existing exclusionary practice of the industry emulates the exclusionary nature of society itself. Indeed, because disability is socially constructed, it necessitates a social solution, and social action [13].

\subsection{Widening of Participation in Tourism Decision-Making}

The fifth element of inclusive tourism development is about widening the participation of marginalised people -in this case, people with disabilities-in tourism decision-making. The intention is to better, and more responsibly, reflect certain interests of the community, as well as wider society, in aspects that directly concern them [2], such as, for instance, in access to transport to access the tourism system $[103,104]$. To this end, it is about counteracting the typically dominant industry-centric perspectives by facilitating favourable terms and inclusive approaches that allow for the active participation of people with disabilities in planning and development [2].

Several studies have reported on the significance of multiple and diverse stakeholder perspectives, participation and collaboration in the development of accessible tourism. Michopoulou and Buhalis [105] offer a comprehensive analysis of accessible tourism stakeholders. Given that people with disabilities themselves have the lived experience of disability and the requirement of various access needs and support, it is especially pertinent that their voices are heard $[18,74,75]$. In practice, however, this stakeholder group is thought to have limited opportunities to contribute to tourism policy, planning and development in a meaningful way. Therefore, "collaborative efforts can be enhanced in the development of accessible tourism to innovatively move the agenda towards inclusive tourism" [104] (p. 676). This also requires future attention to be focused on the consideration of co-creative stakeholder engagement methods to engender collaborative dialogue, equitable inclusion, reciprocal learning and the challenging of existing knowledge gaps and assumptions held by powerful tourism stakeholders [106]. 


\subsection{Changing the Tourism Map to Involve New People and Places}

The sixth element of inclusive tourism development is about reimagining tourism to include new sites of experience and spaces for interaction [2].

Within the literature, much has been written that relates, in part, to changing the tourism map to involve new people and places. This includes considerations of the tourism system at large, in terms of destination management, to the incorporation of the principles of universal design in tourism sites and spaces. It also includes considerations of both the business and social rationales for accessible tourism, and its role in achieving sustainability.

At the destination level, it is both complex and challenging to deliver quality accessible tourism experiences due to the fragmented nature of the industry and lack of collaboration between the tourism and access sectors [104]. Accessibility, at the destination level, then, determines whether, and to what extent, an individual can participate in tourism [29,107]. It is not enough for a single component of the journey to be accessible, if the other components are largely inaccessible. "Until examples of good business practice are identified and promoted, the industry cannot be guided with certainty about the benefits in providing expanded accessible tourism products" [5] (p. 533). Some destinations, namely Europe, the United States and Australia, are conforming to legislative requirements and proactively "developing infrastructure, goods, services, marketing and promotion in alignment with the collaborative processes outlined in the conceptualisation of accessible tourism" [1] (p. 142).

"Ensuring access to travel and tourism opportunities for people living with disability as well as for the entire population requires knowledge and design structures that are inclusive for all citizens" [100] (p. 46). The incorporation of physical accessibility into existing and potential tourism sites and spaces has become increasingly significant, and Darcy et al. [5] have suggested that it is no longer realistic, feasible or ethical to ignore such demands [5]. Not only are various components of the tourism system largely inaccessible, but people with disabilities can face difficulty in negotiating the built environment too [104], which impedes upon their participation and "reduces their independence, dignity, equity and self-determination" [18] (p. 183). A concept central to understanding accessible tourism development is universal design. The principles of universal design distinctively provide positive economic benefits to operators and destinations alike, and socially sustainable outcomes to people with disabilities and wider society, given that it recognises the implications of ageing and disability, and adopts a whole-of-life approach [5].

In addition to universal design as a strategy for more inclusive tourism, it has been suggested that social tourism policy and practice has the potential to contribute to inclusive and sustainable outcomes for people with disabilities [20,94]. Other examples of such socially-based tourism policies and practices include prospects like respite tourism [108] or assisted vacations [109]. That said, people with disabilities access tourism outside of social policies, and such policies are not offered in some countries; hence, future considerations must be directed at development of policies and an inclusive tourism system for all.

\subsection{Promotion of Mutual Understanding and Respect}

The final element of inclusive tourism development is about promoting mutual understanding and respect by way of overcoming negative stereotyping and breaking down the barriers between people [2].

There is evidence that tourism promotional materials perpetuate an ableist gaze [110]. To counter the lack of understanding of disability, previous studies have emphasised the need for increased awareness and knowledge of disability [68,70,88]. They have reported on the value in breaking down the negative attitudinal barriers people with disabilities encounter from others. Examples have included the normalising of disability through better representation of people with disabilities, for instance, in packaging and promotion or through media [66]. Examples have also included: the employment of more enabling language [111], considering more accessible web design and assistive technologies [112], and carrying out disability awareness raising and sensitivity training 
programmes [76]. The transformative potential of accessible tourism requires the continued challenging of stereotypes and stigma, and the ongoing promotion of awareness, acceptance and inclusion. Inclusive attitudes and approaches are integral to the provision of accessibility $[35,72]$ to ensure people with disabilities are treated equitably, and with dignity and respect $[6,10]$.

\section{Conclusions}

Inclusive tourism development is framed as having the potential for a "broader transformative influence within and beyond the tourism industry" [2] (p. 584). There is benefit, therefore, in applying the conceptual framework for inclusive tourism development to accessible tourism, because it is fundamentally about the inclusion of people with disabilities in tourism, and in society. Scheyvens and Biddulph [2] emphasised the importance in confronting constraints to achieving inclusive tourism, arguing that "the prevailing ideology of neoliberalism" is the greatest of constraints [2] (p. 603). This paper used a conceptual approach to recommend a future agenda for more inclusive tourism outcomes that move towards sustainability. In mapping how accessible tourism is currently positioned against the seven elements of inclusive tourism development, we have seen that with regard to disability, the predominant constraint to achieving inclusive tourism is arguably the dominant ableist discourse that "reproduce[s] and reinforce[s] the dominant hegemony and cultural discourse that currently exist[s] around disability" [89] (p. 237). As such, a future agenda posits attention to all seven elements of the inclusive tourism framework for accessible tourism. In order to achieve this, we urge researchers to consider three wider considerations. We would caution, however, that Western and Eastern perspectives, as well as developed and developing contexts, may likely reveal differences among these issues. Equally, a more systematic review of the content of previous accessible tourism literature and that of wider fields, may reveal differing perspectives not captured in the notable examples we mention here.

First, we suggest that a closer examination of the wider disability discourse, including both historical and social perspectives of people with disabilities, is an important starting point for accessible tourism scholarship. "Benefits can accrue if the recognition, understanding and knowledge about the long history of marginalisation and exclusion of this group are taken into account" [104] (p. 678). As individuals and as a collective, we need to recognise our biases, as well as our complicity in accepting, and even perpetuating, the hegemonic hold of ableism [113,114]. Importantly, if disability is indeed a social construct [115], then a social solution can be achieved in and through tourism [13,70,82]. A future agenda must consider this, further leveraging the social model of disability

Second, a future agenda must consider how our academic inquiry can be more participatory and inclusive. If we are to build a sound foundation of knowledge for sustainability, then we need to step outside of our own field and engage with the relevant, related scholarship of other fields, like disability and leisure studies. We need to critically reflect on the consequences of our academic language, and the methods and approaches we adopt for inclusion, equity of participation, collaborative dialogue, reciprocal learning, and for challenging the existing knowledge and assumptions of the dominant stakeholders in sectors which do not necessarily dialogue with each other (such as the tourism and access sectors) for creative social solutions.

Thirdly, a bridge between inquiry, industry and community is needed. Many of the future research directions and practical recommendations we propose as scholars are not filtered through our scholarship. We have to ask, where is our scholarship going, what is being done with it, and is it having an impact? If sustainability is about the future, then this work is of critical importance. Within our own field, this might include inclusive tourism research that looks at language, ethics, researcher positionality and care ethics. Related to this, there is a need for a more accessible pedagogy, where inclusive tourism programmes include students with disabilities but also reflect that diversity in their teaching and curriculum. We also need to advocate collaborative approaches to our research that are embedded in industry priorities and processes for social change. These things are important if we are to consider seriously how we might move from a disabling and exclusionary mindset to that of an 
enabling one that generates inclusion, and by extension, more sustainable outcomes. Our application of the framework of inclusive tourism to examine accessibility reveals we still have some way to go. As such, there is a need to move beyond the conceptual approach we use here to effect change.

Author Contributions: All authors contributed equally to the writing of this paper. All authors have read and agreed to the published version of the manuscript.

Funding: This research received no external funding.

Conflicts of Interest: The authors declare no conflict of interest.

\section{References}

1. Darcy, S.; McKercher, B.; Schweinsberg, S. From tourism and disability to accessible tourism: A perspective article. Tour. Rev. 2020, 75, 140-144. [CrossRef]

2. Scheyvens, R.; Biddulph, R. Inclusive tourism development. Tour. Geogr. 2018, 20, 589-609. [CrossRef]

3. Singleton, J.; Darcy, S. 'Cultural life', disability, inclusion and citizenship. Moving beyond leisure in isolation. Ann. Leis. Res. 2013, 183-192. [CrossRef]

4. World Health Organization; World Bank. World Report on Disability; World Health Organization: Geneva, Switzerland, 2011.

5. Darcy, S.; Cameron, B.; Pegg, S. Accessible tourism and sustainability: A discussion and case study. J. Sustain. Tour. 2010, 18, 515-537. [CrossRef]

6. Daruwalla, P.; Darcy, S. Personal and societal attitudes to disability. Ann. Tour. Res. 2005, 32, 549-570. [CrossRef]

7. United Nations. World Population Ageing 2015; United Nations: New York, NY, USA, 2015.

8. Office for Disability Issues. The New Zealand Disability Strategy: Making a World of Difference; Office for Disability Issues and Ministry of Social Development: Wellington, New Zealand, 2001.

9. Bowen, J.R.; Gibson, F.L.; Hand, P.J. Educational outcome at 8 years for children who were born extremely prematurely: A controlled study. J. Child Health Care 2002, 38, 438-444. [CrossRef]

10. Darcy, S.; Dickson, T. A whole-of-life approach to tourism: The case for accessible tourism experiences. J. Hosp. Tour. Manag. 2009, 16, 32-44. [CrossRef]

11. Kittay, E.F. Equality, dignity and disability. In Perspectives on Equality: The Second Seamus Heaney Lectures; Waldron, M.A., Lyons, F., Eds.; Liffey: Dublin, Ireland, 2002; pp. 95-122.

12. Philip, G.; Rogers, C.; Weller, S. Understanding care and thinking with care. In Critical Approaches to Care: Understanding Caring Relations, Identities and Cultures; Rogers, C., Weller, S., Eds.; Routledge: London, UK, 2012; pp. 1-12.

13. Darcy, S.; Buhalis, D. Conceptualising disability. In Accessible Tourism: Concepts and Issues; Channel View: Bristol, UK, 2011; pp. 21-42.

14. Vila, T.D.; Darcy, S.; Gonzalez, E.A. Competing for the disability tourism market-A comparative exploration of the factors of accessible tourism competitiveness in Spain and Australia. Tour. Manag. 2015, 111-116. [CrossRef]

15. Liu, C.H.; Tzeng, G.H.; Lee, M.H.; Lee, P.Y. Improving metro-airport connection service for tourism development: Using hybrid MCDM models. Tour. Manag. Perspect. 2013, 6, 95-107. [CrossRef]

16. Dwyer, L. Trends underpinning global tourism in the coming decade. In Global Tourism; Theobald, W., Ed.; Heinemann: Oxford, UK, 2005; pp. 529-545.

17. Higgins-Desbiolles, F. More than an 'industry': The forgotten power of tourism as a social force. Tour. Manag. 2006, 27, 1192-1208. [CrossRef]

18. Michopoulou, E.; Darcy, S.; Ambrose, I.; Buhalis, D. Accessible tourism futures: The world we dream to live in and the opportunities we hope to have. J. Tour. Futures 2015, 1, 179-188. [CrossRef]

19. McCabe, S.; Diekmann, A. The rights to tourism: Reflections on social tourism and human rights. Tour. Recreat. Res. 2015, 40, 194-204. [CrossRef]

20. Minnaert, L.; Maitland, R.; Miller, G. Tourism and social policy: The value of social tourism. Ann. Tour. Res. 2009, 36, 316-334. [CrossRef]

21. United Nations. Convention on the Rights of Persons with Disabilities; United Nations: New York, NY, USA, 2006. 
22. United Nations. Transforming our World: The 2030 Agenda for Sustainable Development; United Nations: New York, NY, USA, 2015.

23. United Nations. Disability and Development Report; United Nations: New York, NY, USA, 2018.

24. United Nations Development Programme. Inclusive Development; United Nations: New York, NY, USA, 2016.

25. Edgell, D.L. Managing Sustainable Tourism: A Legacy for the Future; Routledge: New York, NY, USA, 2019.

26. Biddulph, R.; Scheyvens, R. Introducing inclusive tourism. Tour. Geogr. 2018, 20, 583-588. [CrossRef]

27. Oliver, M.; Barnes, C. The New Politics of Disablement; Palgrave Macmillan: Hampshire, UK, 2012.

28. Darcy, S.; Taylor, T. Disability citizenship: An Australian human rights analysis of the cultural industries. Leis. Stud. 2009, 28, 419-442. [CrossRef]

29. Belanger, C.; Jolin, L. The International Organisation of Social Tourism (ISTO) working towards a right to holidays and tourism for all. Curr. Issues Tour. 2011, 14, 475-482. [CrossRef]

30. Shaw, G.; Coles, T. Disability, holiday making and the tourism industry in the UK: A preliminary survey. Tour. Manag. 2004, 25, 397-403. [CrossRef]

31. Smith, R.W. Leisure of disabled tourists: Barriers to participation. Ann. Tour. Res. 1987, 14, 376-389. [CrossRef]

32. Figueiredo, E.; Eusebio, C.; Kastenholz, E. How diverse are tourists with disabilities? A pilot study on accessible leisure tourism experiences in Portugal. Int. J. Tour. Res. 2012, 14, 531-550. [CrossRef]

33. Sirgy, M. Toward a quality-of-life theory of leisure travel satisfaction. J. Travel Res. 2010, 49, $246-260$. [CrossRef]

34. Darcy, S. Inherent complexity: Disability, accessible tourism and accommodation information preferences. Tour. Manag. 2010, 31, 816-826. [CrossRef]

35. Yau, M.; McKercher, B.; Packer, T. Travelling with a disability: More than an access issue. Ann. Tour. Res. 2004, 31, 946-960. [CrossRef]

36. Crouch, G.; Ritchie, B. Tourism, competitiveness and societal prosperity. J. Bus. Res. 1999, 44, 137-152. [CrossRef]

37. Fletcher, R. Sustaining tourism, sustaining capitalism? The tourism industry's role in global capitalist expansion. Tour. Geogr. 2011, 13, 443-461. [CrossRef]

38. Telfer, D. Development studies and tourism. In The SAGE Handbook of Tourist Studies; Jamal, T., Robinson, M., Eds.; Sage: London, UK, 2009; pp. 146-165.

39. Hall, C.M. Rethinking the geography of tourism and contemporary mobility. Geogr. Res. 2005, 43, 125-139. [CrossRef]

40. Tribe, J. Tribes, territories and networks in the tourism academy. Ann. Tour. Res. 2010, 37, 7-33. [CrossRef]

41. Cole, S.; Morgan, N. Introduction: Tourism and inequalities. In Tourism and Inequality: Problems and Prospects; CABI: Oxfordshire, UK, 2010; pp. xvii-xxv.

42. Humberstone, B. Standpoint Research: Multiple Versions of Reality in Tourism Theorising and Research; Routledge: London, UK, 2004.

43. Kastenholz, E.; Eusebio, C.; Figueiredo, E. Contributions of tourism to social inclusion of persons with disability. Disabil. Soc. 2015, 30, 1259-1281. [CrossRef]

44. Higgins-Desbiolles, F.; Carnicelli, S.; Krolikowski, C.; Wijesinghe, G.; Boluk, K. Degrowing tourism: Rethinking tourism. J. Sustain. Tour. 2019, 27, 1926-1944. [CrossRef]

45. Ateljevic, I.; Pritchard, A.; Morgan, N.J. Editors' introduction: Promoting an academy of hope in tourism enquiry. In The Critical Turn in Tourism Studies: Innovative Research Methodologies; Elsevier: Oxford, UK, 2007; pp. 1-10.

46. Pritchard, A.; Morgan, N.; Ateljevic, I. Hopeful tourism: A new transformative perspective. Ann. Tour. Res. 2011, 38, 941-963. [CrossRef]

47. Schwarzin, L. To act as though the future mattered: A framework for hopeful tourism education. In The Critical Turn in Tourism Studies: Creating an Academy of Hope; Ateljevic, A., Pritchard, A., Morgan, N., Eds.; Routledge: Oxford, UK, 2007; pp. 135-148.

48. Small, J.; Harris, C.; McIntosh, A. Whose Body is Welcome in Paradise? In Proceedings of the CAUTHE 2008 Conference: Where the Bloody Hell are we? Surfers Paradise, QLD, Australia, 11-14 February 2008; Griffith University: Gold Coast, QLD, Australia, 2008. 
49. Morgan, N.; Pritchard, A.; Ateljevic, I. Epilogue: Hopeful tourism: An unfolding perspective. In The Critical Turn in Tourism Studies: Creating an Academy of Hope; Ateljevic, A., Pritchard, A., Morgan, N., Eds.; Routledge: Oxford, UK, 2007; pp. 219-223.

50. Pritchard, A.; Morgan, N. De-centring tourism's intellectual universe, or traversing the dialogue between change and tradition. In The Critical Turn in Tourism Studies: Creating an Academy of Hope; Ateljevic, A., Pritchard, A., Morgan, N., Eds.; Routledge: Oxford, UK, 2007; pp. 11-28.

51. Boluk, K.A.; Cavaliere, C.T.; Higgins-Desbiolles, F. A critical framework for interrogating the United Nations Sustainable Development Goals 2030 Agenda in tourism. J. Sustain. Tour. 2019, 27, 847-864. [CrossRef]

52. Groschl, S. Persons with disabilities: A source of non-traditional labour for Canada's hotel industry. Cornell Hosp. Q. 2005, 46, 258-274. [CrossRef]

53. Bengisu, M.; Balta, S. Employment of the workforce with disabilities in the hospitality industry. J. Sustain. Tour. 2011, 19, 35-37. [CrossRef]

54. Kalargyrou, V. Gaining a competitive advantage with disability inclusion initiatives. J. Hum. Resour. Hosp. Tour. 2014, 13, 120-145. [CrossRef]

55. Kalargyrou, V.; Volis, A.A. Disability inclusion initiatives in the hospitality industry: An exploratory study of industry leaders. J. Hum. Resour. Hosp. Tour. 2014, 13, 430-454. [CrossRef]

56. Groschl, S. Current human resources practices affecting the employment of persons with disabilities in selected Toronto hotels. Int. J. Hosp. Tour. Adm. 2004, 5, 15-30. [CrossRef]

57. Groschl, S. An exploration of HR policies and practices affecting the integration of persons with disabilities in the hotel industry in major Canadian tourism destinations. Int. J. Hosp. Manag. 2007, 26, 666-686. [CrossRef]

58. Groschl, S. Presumed incapable: Exploring the validity of negative judgments about persons with disabilities and their employability in hotel operations. Cornell Hosp. Q. 2012, 54, 114-123. [CrossRef]

59. Houtenville, A.; Kalargyrou, V. People with disabilities: Employers' perspectives on recruitment practices, strategies, and challenges in leisure and hospitality. Cornell Hosp. Q. 2012, 53, 40-52. [CrossRef]

60. Jasper, C.R.; Waldhart, P. Employer attitudes on hiring employees with disabilities in the leisure and hospitality industry: Practical and theoretical implications. Int. J. Contemp. Hosp. Manag. 2013, 25, 577-594. [CrossRef]

61. Paez, P.; Arendt, S.W. Managers' attitudes towards people with disabilities in the hospitality industry. Int. J. Hosp. Tour. Adm. 2014, 15, 172-190. [CrossRef]

62. Kuo, P.-J.; Kalargyrou, V. Consumers' perspectives on service staff with disabilities in the hospitality industry. Int. J. Contemp. Hosp. Manag. 2014, 26, 164-182. [CrossRef]

63. Kalargyrou, V.; Barber, N.A.; Kuo, P.-J. The impact of disability on guests' perceptions of service quality delivery in the hospitality industry. Int. J. Contemp. Hosp. Manag. 2018, 30, 3632-3655. [CrossRef]

64. Kalargyrou, V.; Kalargiros, E.; Kutz, D. Social entrepreneurship and disability inclusion in the hospitality industry. Int. J. Hosp. Tour. Adm. 2020, 21, 308-334. [CrossRef]

65. Marks, J.; Hidden, K. Brownies \& Downies: Coffee, culture and community: A social innovation that supports the intellectually disabled. EMCS 2018, 8, 1-15. [CrossRef]

66. McIntosh, A.; Harris, C. Representations of hospitality at The Special Needs Hotel. Int. J. Hosp. Manag. 2018, 75, 153-159. [CrossRef]

67. Burnett, J.J.; Bender-Baker, H. Assessing the travel-related behaviours of the mobility-disabled consumer. J. Travel Res. 2001, 40, 4-11. [CrossRef]

68. Gladwell, N.J.; Bedini, L.A. In search of lost leisure: The impact of caregiving on leisure travel. Tour. Manag. 2004, 25, 685-693. [CrossRef]

69. Daniels, M.; Rodgers, E.; Wiggins, B. 'Travel tales': An interpretive analysis of disabilities. Tour. Manag. 2005, 26, 919-930. [CrossRef]

70. Richards, V.; Pritchard, A.; Morgan, N.J. (Re)envisioning tourism and visual impairment. Ann. Tour. Res. 2010, 37, 1097-1116. [CrossRef]

71. Stumbo, N.; Pegg, S. Travellers and tourists with disabilities: A matter of priorities and loyalties. Tour. Rev. 2005, 8, 195-209. [CrossRef]

72. Darcy, S.; Pegg, S. Towards strategic intent: Perceptions of disability service provision amongst hotel accommodation managers. Int. J. Hosp. Manag. 2011, 30, 468-476. [CrossRef]

73. Huh, C.; Singh, A. Families travelling with a disabled member: Analysing the potential of an emerging niche market segment. Tour. Hosp. Res. 2007, 7, 212-229. [CrossRef] 
74. O'Neill, M.; Knight, J. Disability tourism dollars in Western Australia hotels. Hosp. Rev. 2000, 18, 72-88.

75. Gillovic, B.; McIntosh, A. Stakeholder perspectives of the future of accessible tourism in New Zealand. J. Tour. Futures 2015, 1, 223-239. [CrossRef]

76. Card, J.; Cole, S.; Humphrey, A. A comparison of the accessibility and attitudinal barriers model: Travel providers and travellers with physical disabilities. Asia Pac. J. Tour. Res. 2006, 11, 161-175. [CrossRef]

77. Buhalis, D.; Michopoulou, E. Information-enabled tourism destination marketing: Addressing the accessibility market. Curr. Issues Tour. 2011, 14, 145-168. [CrossRef]

78. Dwyer, L.; Darcy, S. Economic contribution of tourists with disabilities: An Australian approach and methodology. In Accessible Tourism: Concepts and Issues; Buhalis, D., Darcy, S., Eds.; Channel View: Bristol, UK, 2011; pp. 213-239.

79. Ambrose, I.; Darcy, S.; Buhalis, D. Introduction. In Best Practice in Accessible Tourism: Inclusion, Disability, Ageing Population and Tourism; Channel View: Bristol, UK, 2012; pp. 1-15.

80. Packer, T.; Small, J.; Darcy, S. Tourist Experiences of Individuals with Vision Impairment; Sustainable Tourism Cooperative Research Centre: Gold Coast, QLD, Australia, 2008.

81. Zajadacz, A. Evolution of models of disability as a basis for further policy changes in accessible tourism. J. Tour. Futures 2015, 1, 187-200. [CrossRef]

82. McIntosh, A. The hidden side of travel: Epilepsy and tourism. Ann. Tour. Res. 2020, 81, 1-10. [CrossRef]

83. Small, J.; Darcy, S. Understanding tourist experience through embodiment: The contribution of critical tourism and disability studies. In Accessible Tourism: Concepts and Issues; Buhalis, D., Darcy, S., Eds.; Channel View: Bristol, UK, 2011; pp. 72-96.

84. McKercher, B.; Darcy, S. Re-conceptualising barriers to travel by people with disabilities. Tour. Manag. Perspect. 2018, 26, 59-66. [CrossRef]

85. Small, J.; Darcy, S.; Packer, T. The embodied tourist experiences of people with vision impairment: Management implications beyond the visual gaze. Tour. Manag. 2012, 33, 941-950. [CrossRef]

86. Small, J. Interconnecting mobilities on tour: Tourists with vision impairment partnered with sighted tourists. Tour. Geogr. 2015, 17, 76-90. [CrossRef]

87. Ray, N.M.; Ryder, M.E. 'Ebilities' tourism: An exploratory discussion of the travel needs and motivations of the mobility-disabled. Tour. Manag. 2003, 24, 57-72. [CrossRef]

88. Innes, A.; Page, S.J.; Cutler, C. Barriers to leisure participation for people with dementia and their carers: An exploratory analysis of carer and people with dementia's experiences. Dementia 2016, 15, 1643-1665. [CrossRef] [PubMed]

89. Gillovic, B. Experiences of Care at the Nexus of Intellectual Disability and Leisure Travel. Ph.D. Thesis, University of Waikato, Hamilton, New Zealand, 2019.

90. Devile, E.; Kastenholz, E. Accessible tourism experiences: The voice of people with visual disabilities. JPRTLE 2018, 10, 265-285. [CrossRef]

91. Darcy, S. (Dis)embodied air travel experiences: Disability, discrimination and the affect of a discontinuous air travel chain. J. Hosp. Tour. Manag. 2002, 19, 91-101. [CrossRef]

92. Lehto, X.; Luo, W.; Miao, L.; Ghiselli, R.F. Shared tourism experience of individuals with disabilities and their caregivers. J. Dest. Mark. Manag. 2017, 8, 185-193. [CrossRef]

93. Poria, Y.; Timothy, D.J. Where are the children in tourism research? Ann. Tour. Res. 2014, 47, 77-95. [CrossRef]

94. McCabe, S. Who needs a holiday? Evaluating social tourism. Ann. Tour. Res. 2009, 36, 667-688. [CrossRef]

95. Pagan, R. Time allocation of disabled individuals. Soc. Sci. Med. 2012, 84, 80-93. [CrossRef]

96. Blichfeldt, B.S.; Nicolaisen, J. Disabled travel: Not easy, but doable. Curr. Issues Tour. 2011, 14, 79-102. [CrossRef]

97. Eichhorn, V.; Miller, G.; Tribe, J. Tourism: A site of resistance strategies of individuals with a disability. Ann. Tour. Res. 2013, 43, 578-600. [CrossRef]

98. Sedgley, D.; Pritchard, A.; Morgan, N.; Hanna, P. Tourism and autism: Journeys of mixed emotions. Ann. Tour. Res. 2017, 66, 14-25. [CrossRef]

99. Aitchison, C. Exclusive discourses: Leisure studies and disability. Leis. Stud. 2009, 28, 375-386. [CrossRef]

100. Eichhorn, V.; Buhalis, D. Accessibility: A key objective for the tourism industry. In Accessible Tourism: Concepts and Issues; Buhalis, D., Darcy, S., Eds.; Channel View: Bristol, UK, 2011; pp. 46-61.

101. Small, J. Women's holidays: Disruption of the motherhood myth. Tour. Rev. 2005, 9, 139-154. [CrossRef] 
102. Thomas, C. Sociologies of Disability, 'Impairment', and Chronic Illness: Ideas in Disability Studies and Medical Sociology; Palgrave: London, UK, 2007.

103. Hine, J.; Mitchell, F. 'Better for everyone?' Travel experiences and transport exclusion. Urban Stud. 2001, 38, 319-332. [CrossRef]

104. Nyanjom, J.; Boxall, K.; Slaven, J. Towards inclusive tourism? Stakeholder collaboration in the development of accessible tourism. Tour. Geogr. 2018, 20, 675-697. [CrossRef]

105. Michopoulou, E.; Buhalis, D. Stakeholder analysis of accessible tourism. In Accessible Tourism: Concepts and Issues; Buhalis, D., Darcy, S., Eds.; Channel View: Bristol, UK, 2011; pp. 260-273.

106. McIntosh, A.; Cockburn-Wootten, C. Uncovering absences and gaps: Using Ketso in qualitative research for accessible tourism. J. Qual. Res. Tour. 2020. (forthcoming).

107. Israeli, A. A preliminary investigation of the importance of site accessibility factors for disabled tourists. J. Travel. Res. 2002, 41, 101-104. [CrossRef]

108. Hunter-Jones, P. Informal care, leisure and leisure travel: A UK perspective. Tour. Cult. Commun. 2006, 7, 39-48. [CrossRef]

109. Wilz, G.; Fink-Heitz, M.F. Assisted vacations for men with dementia and their caregiving spouses: Evaluation of health-related effects. Gerontologist 2008, 48, 115-120. [CrossRef]

110. Benjamin, S.; Bottone, E.; Lee, M. Beyond accessibility: Exploring the representation of people with disabilities in tourism marketing materials. J. Sustain. Tour. 2020. (forthcoming). [CrossRef]

111. Gillovic, B.; McIntosh, A.; Darcy, S.; Cockburn-Wootten, C. Enabling the language of accessible tourism. J. Sustain. Tour. 2018, 26, 615-630. [CrossRef]

112. Puhretmair, F.; Nussbaum, G. Web design, assistive technologies and accessible tourism. In Accessible Tourism: Concepts and Issues; Buhalis, D., Darcy, S., Eds.; Channel View: Bristol, UK, 2011; pp. 274-286.

113. Oliver, M. Changing the social relations of research production? Disabil. Soc. 1992, 7, 101-114. [CrossRef]

114. Oliver, M. Understanding Disability: From Theory to Practice; Palgrave Macmillan: Hampshire, UK, 2009.

115. Gleeson, B. Geographies of Disability; Routledge: London, UK, 1999.

Publisher's Note: MDPI stays neutral with regard to jurisdictional claims in published maps and institutional affiliations.

(C) 2020 by the authors. Licensee MDPI, Basel, Switzerland. This article is an open access article distributed under the terms and conditions of the Creative Commons Attribution (CC BY) license (http://creativecommons.org/licenses/by/4.0/). 